\title{
International Comparative and Competitive Advantage of Post-Soviet Countries in Tourism
}

\author{
Famil Majidli ${ }^{1}$ \\ ${ }^{1}$ Azerbaijan State University of Economics, Azerbaijan \\ Correspondence: Famil Majidli, Azerbaijan State University of Economics, Azerbaijan.
}

Received: May 10, 2020

Accepted: September 11, 2020

Online Published: September 13, 2020

doi:10.5430/rwe.v11n5p369

URL: https://doi.org/10.5430/rwe.v11n5p369

\begin{abstract}
In this study, the comparative and competitive advantage of Post-Soviet countries in the tourism sector is examined. Firstly, whether the tourism sector of the countries included in the sample developed between 1995 and 2018 was examined. Revealed Comparative Advantages Index which is developed by Balassa and Expanded Balassa Index were used to analyze the comparative and competitive advantage of countries, respectively, which are the main purpose of the study. The results of the study, which are calculated based on the data obtained from the database of the World Bank, provide information especially regarding the advantageous position of Georgia regarding Balassa Index. In addition to Georgia, Armenia, Kyrgyz Republic, Moldova, Tajikistan, Azerbaijan, Estonia and Uzbekistan have international comparative advantage and when the situation of the countries is evaluated over the EB index it is concluded to, Tajikistan and Georgia have strong, Kyrgyz Republic and Moldova have medium, Latvia, Estonia, Armenia, Lithuania and Belarus have weak competitive advantage. The research is important in terms of the policies that Post Soviet countries will form within the scope of tourism sectors.
\end{abstract}

Keywords: Post-Soviet countries, tourism, revealed comparative advantage, international competitiveness, Balassa Index

\section{Introduction}

From the second half of the twentieth century, new economic, socio-cultural, environmental and psychological habits acquired by people around the world have rapidly increased international mobility, enabling the further development of the tourism sector, which countries did not attach great importance to before. With the phenomenon of globalization that emerged especially after the 1980s, people's travels to foreign countries have gained momentum, whether for business purposes or other personal purposes. Until the 1990s, while the countries of the world got their share in economic terms from this international mobility, the Republics included in the Soviet Union could not take advantage of the tourism sector due to their closed economic system.

All tourism activities in these countries were carried out under the control of the central government. The number of incoming tourists and the tourists going abroad were subject to a certain limit. For example, prior to independence, tourism in Kyrgyzstan was under the supervision of the State Committee for Tourism, the International Youth Tourism Bureau (MMTB Sputnik), the Tourism and Travel Council and the Tien Shan International Mountaineering Center. In this context, the State Committee for Tourism was responsible for receiving foreign guests, the International Mountaineering Center - for mountaineering, Sputnik - for youth tourism, and the Tourism and Travel Council - for organizing domestic tourism. Until 1991, according to the policy of the Soviet government and budget subsidies of prices, tourist movements were more called sports, entertainment and medical, and the term "tourism" in most cases was used in connection with the service of foreign tourists (Akbulaev N. , 2004).

With the collapse of the Soviets, these countries have further contributed to the growth of the international tourism mobility both by opening their doors to the outside world and by traveling the citizens of these countries to foreign countries. In the report published by the World Tourism Organization (2020), the tourism sector is shown as the third largest sector after fuels and chemicals in the ranking of exports (Figure 1.). The fact that the tourism sector is the largest and fastest growing economic sector in the international framework has also increased the interest of countries in this sector. Furthermore, besides the economic returns promised by the sector, social returns that can be evaluated in terms of human capital are also important for tourism to be the favorite sector of the countries. 


\begin{tabular}{lrrrrr} 
& & & \multicolumn{3}{c}{ USD billion } \\
\cline { 2 - 6 } Rank & 2010 & 2015 & 2016 & 2017 & 2018 \\
\hline World & & & & & \\
1 Fuels & 2,395 & 1,799 & 1,476 & 1,976 & 2,408 \\
2 Chemicals & 1,694 & 1,844 & 1,816 & 1,985 & 2,237 \\
\hline International Tourism (BOP Travel \& Passenger transport) & 1,152 & 1,445 & 1,469 & 1,590 & 1,717 \\
$\quad$ - International Tourism Receipts & 980 & 1,228 & 1,254 & 1,352 & 1,462 \\
$\quad$ - International Passenger Transport & 171 & 217 & 215 & 238 & 256 \\
4 Automotive products & 1,094 & 1,330 & 1,365 & 1,466 & 1,547 \\
5 Food & 1,116 & 1,330 & 1,352 & 1,474 & 1,532 \\
6 Textiles and clothing & 608 & 741 & 725 & 760 & 807 \\
7 Telecommunications equipment & 585 & 706 & 685 & 652 & 749 \\
8 Mining products other than fuels & 679 & 567 & 536 & 654 & 727 \\
9 Transport equipment other than automotive products & 592 & 694 & 667 & 691 & 706 \\
10 Integrated circuits and electronic components & 484 & 526 & 526 & 636 & 703 \\
\hline
\end{tabular}

Figure 1. Export earnings by sectors

Source: UNWTO. (2020). World Tourism Barometer

For the former Soviet countries, which are young actors in the free market system, the tourism sector is of great importance to stabilize the balance of payments by bringing foreign currency to the country's economy. Moreover, international mobility is also important for the citizens of the country to adapt to the free market culture structure in a shorter time. Besides the positive effects of the tourism industry on post-Soviet countries, the tourism potential of these countries attracts the citizens of other countries, which has led to the emergence of new tourism destinations.

Some post-Soviet countries that understand the importance of tourism advantages are implementing supportive policies at the government level to develop this sector. However, supporting this sector also means significant investment. Many developing countries - including Azerbaijan - need investment costs that can be financed by exports of primary goods or tourism-related services (Akbulaev \& Mirzayeva, 2020).

So how effectively do post-Soviet countries use their tourism potential? Do these countries have competitive advantage within the scope of international competition? These questions form the main research topic of the article. In the article, the sectoral structure of the tourism economies of the countries mentioned was first indicated, and based on the data of the World Bank and the World Tourism Organization, the market share of the countries, the share of the tourism sector in the GDP, and the information about the tourists entering the country were interpreted. In the later part of the article, the global competitiveness of Post-Soviet countries in tourism has been analyzed in the context of international comparative and competitive advantage.

This study was carried out to analyze the global competitiveness of Post-Soviet countries based on the "Comparative Advantages" approach, and it was emphasized which countries are in an advantageous position by using the RCA formula developed by Balassa (1965). In addition to the Balassa index, the competitiveness of the tourism sectors of the countries in the sample was also calculated with the Extended Balassa (EB) index by Algieri, Aquino, \& Succurro (2018). The main purpose of using the EB index is not only to evaluate the export status of countries such as the traditional Balassa index, but also to try to explain the level of international competition by including the import figures.

\section{Literature Review}

With the transformation of the world economy into a global form in the last decades, countries and companies have now entered into an international competition. Within this scope, each country and company implement policies to protect and increase their competitive power on the basis of individual sectors. From this point of view, researches to determine competitive power are of great importance. (Miral, 2006) 
The basis of international competitiveness is based on Ricardo's "Comparative Advantages Theory" and Hecksher and Ohlin's "Factor Equipment Theory". The main approach we will follow is the "Comparative Advantage" approach, which was put forward by David Ricardo (1821) and one of the most important assumptions of the international trade theory. Based on this approach, although the first studies to determine the competitiveness of a country were carried out by Liesner in 1958, Balassa further developed the index of Liesner, which is also known as the Revealed Comparative Advantage (RCA) index described in the literature (Utkulu \& Seymen, 2004). The index developed by Liesner is as follows (Xij: country i`s exports of $\mathrm{j}$ good. Xnj: country $\mathrm{n}$ or group of countries exports of $\mathrm{j}$ good. In Liesner's study, country $\mathrm{i}$ is England and country group $\mathrm{n}$ is the Common Market.) (Liesner, 1958):

$$
\mathrm{RCA}(\mathrm{L})=\mathrm{Xij} / \mathrm{Xnj}
$$

As stated above, this approach of Liesner was developed by Balassa, while Balassa's approach explains the comparative advantages among international trading countries, as well as revealing the strong and weak sectors of these countries. Balassa states that the export data are more reliable to explain the comparative advantage in the current conditions. Because the customs tax and other restrictive measures, which emerge as additional costs due to the protectionist policies of the countries in the import process, are different in each country, so the export and import rates are affected by these differences. According to Balassa, if a customs duty is determined at the same rate for a product in each country in the case of export of products, there will be no deviation in the export performance criterion (Balassa, 1965). Balassa formulated the index as follows (xij: country j's exports of goods $\mathrm{i}, \mathrm{Xj}$ : country's j's total exports, xiw: world country's exports of goods i, Xw: total world export):

$$
\mathrm{RCA}(\mathrm{B})=(\mathrm{xij} / \mathrm{Xj}) /(\mathrm{xiw} / \mathrm{Xw})
$$

In addition to being the most frequently used index to evaluate the competitiveness of countries on the basis of individual sectors, Balassa index has also formed the basis for new competition indices developed later (Kuşat, 2019). Among these indices, the most frequently encountered in the literature are the ones developed by Vollrath. Vollrath mentions 3 different methods to measure the competitiveness of countries; relative trade advantage (RTA), the logarithm of relative export advantage (In RXA), revealed competitiveness (RC) (Vollrath, 1991). The relative trade advantage index of Vollrath is as follows (xij: country j's exports of goods $\mathrm{i}, \mathrm{Xj}$ : total exports of country $\mathrm{j}, \mathrm{Xni}: \mathrm{n}$ group countries` total exports of i goods, Xn: total exports of $n$ group countries, Mij: country j's import of goods i, Mj: total imports of country $\mathrm{j}$, Mni: $\mathrm{n}$ group countries` total imports of goods $\mathrm{i}$, Mn: total imports of $\mathrm{n}$ group countries):

$$
\begin{gathered}
\text { RTA = RXA - RMA } \\
\text { RXA }=\left(\mathrm{Xij}_{\mathrm{Xj}} / \mathrm{X} /(\mathrm{Xni} / \mathrm{Xn})\right. \\
\mathrm{RMA}=(\mathrm{Mij} / \mathrm{Mj}) /(\mathrm{Mni} / \mathrm{Mn})
\end{gathered}
$$

RXA: Relative export advantage, RMA: Relative import advantage.

GÜMÜŞ \& HIZIROĞLU (2015), Algieri (2006), Erkan \& Bozduman (2019) Kuşat (2019), Algieri, Aquino, \& Succurro (2018), Jackman vd. (2011), Seyoum (in the study, besides the tourism sector, other service sectors were also examined) (2007) used the Balassa index in their studies to determine competitiveness in the tourism sector.

When we examine the studies conducted in the literature to evaluate the competitiveness of countries on the tourism sector, we see that the most frequently used indicator is the Travel and Tourism Competitiveness Index (TTCI). TTCI is the most complex index published by the World Economic Forum. TTCI consists of four subindexes and these subindexes are composed of 14 different pillars (Calderwood \& Soshkin, 2019). In summary, this index evaluates the economic, environmental and cultural factors that may affect the tourism sector. Leung \& Baloglu (2013), Nazmfar et al. (2019), Das \& Dirienzo (2010) and Kantarci \& Develioglu (2013) used TTCI indicators in their analysis of competitiveness in the tourism industry.

\section{Sectoral Structure of Tourism in Post-Soviet Countries}

In the report titled "World Tourism Barometer" published by the World Tourism Organization in 2020, it is stated that the tourism sector continues its global development. Namely, a $4 \%$ increase in the number of total arrivals was observed. Recent data on total international tourism receipts revealed that revenues increased by $4.4 \%$ in 2018 (Figure 2.). According to these data, the increase in total tourism revenues in the last 10 years has been above the increase of the world GDP. According to 2019 data, the economies of Post-Soviet countries were also positively affected by the increase in the tourism sector. In the report, it is stated that the tourism sector in Estonia, Moldova states has increased above the average of the Central and Eastern European countries where these countries are located, Georgia has continued its robust growth trend and double digit growth figures have been reached in 
countries such as Azerbaijan, Armenia, Lithuania, Kazakhstan and Uzbekistan (United Nations World Tourism Organization (UNWTO), 2020). In addition, Russia switched to a free visa application for the Saint Petersburg region to attract more tourists.

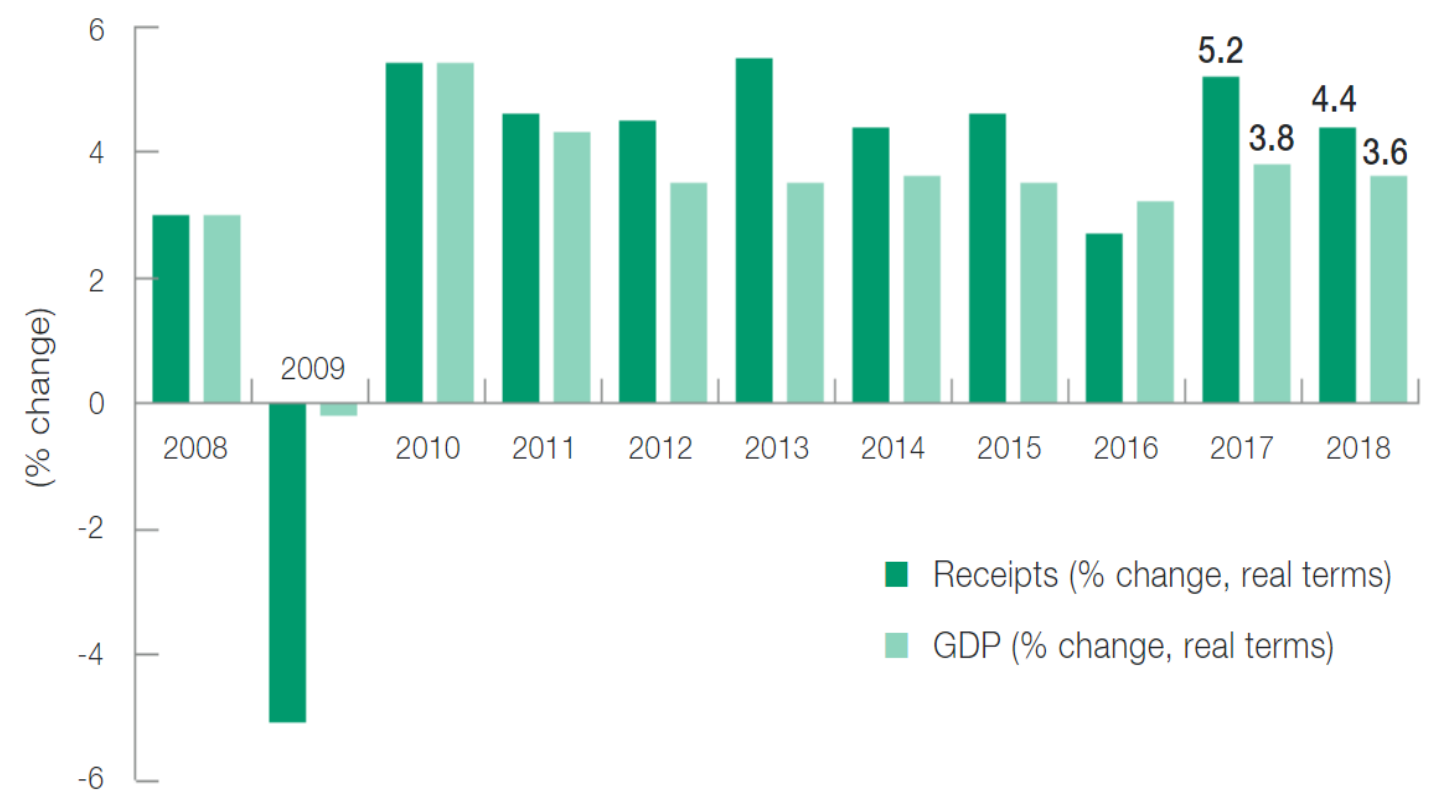

Figure 2. International tourism receipts and world GDP (change \%)

Source: UNWTO. (2019). International tourism highlights.

In the following sections of the chapter, the main indicators related to the tourism markets of Post-Soviet countries are evaluated by years. In this context, the share of international tourism receipts of the countries within the GDP is evaluated first. As can be seen from Table 1, Post-Soviet countries could not fully benefit from the advantages of the tourism sector in the first years of their independence, only in Estonia tourism revenues made up 10\% of the GDP. Estonia was followed by Moldova, Azerbaijan, Lithuania and Russian Federation with 4.05\%, 2.85\%, 1.30\% and $1.09 \%$ respectively. In other countries, the share of tourism revenues in the GDP were below $1 \%$. In the following years, we see that the tourism sector has developed in these countries. Namely, the share of tourism revenues in GDP was above $1 \%$ in all countries except Uzbekistan, among countries whose data was published in 2000. In 2018, we see that there has been a significant progress especially in the position of Georgia. Namely, international tourism revenues in Georgia constitute approximately $20 \%$ of GDP. Other notable countries are Armenia, Azerbaijan and Kyrgyz Republic, with rates of 9.95\%, 6.03\% and 6.02\%. The share of tourism revenues in GDP of Estonia (7.59\%) in 2018 is less than compared to 1995 and 2000. In summary, these data show that the Georgian economy is affected by the tourism sector more than other countries, which creates a basis for the mentioned country to define itself as a tourism country.

Table 1. Share of international tourism receipts in GDP of Post-Soviet countries (\%)

\begin{tabular}{lllllll}
\hline & 1995 & 1996 & 2015 & 2016 & 2017 & 2018 \\
\hline Armenia & 0.95 & 1.13 & 9.06 & 9.37 & 9.89 & 9.95 \\
Azerbaijan & 2.85 & 1.79 & 4.78 & 7.54 & 7.86 & 6.03 \\
Belarus & 0.20 & 0.41 & 1.79 & 2.14 & 2.05 & 2.05 \\
Estonia & 10.05 & 11.82 & 8.21 & 7.98 & 7.93 & 7.59 \\
Georgia & - & - & 13.70 & 15.29 & 18.29 & 19.99 \\
Kazakhstan & 0.76 & 1.23 & 0.99 & 1.48 & 1.41 & 1.48
\end{tabular}




\begin{tabular}{lllllll} 
Kyrgyz Republic & 0.30 & 0.22 & 7.22 & 7.00 & 6.23 & 6.02 \\
Latvia & 0.64 & 3.88 & 3.30 & 3.24 & 3.15 & 3.07 \\
Lithuania & 1.30 & 4.11 & 2.79 & 2.81 & 2.78 & 2.66 \\
Moldova & 4.05 & 2.95 & 3.87 & 4.26 & 4.58 & 4.37 \\
Russian Federation & 1.09 & 1.81 & 0.97 & 1.00 & 0.95 & 1.13 \\
Tajikistan & - & - & 1.86 & 2.15 & 2.40 & 2.27 \\
Turkmenistan & - & 0.55 & - & - & - & - \\
Ukraine & 0.40 & 1.01 & 1.83 & 1.85 & 1.80 & 1.73 \\
Uzbekistan & - & 0.11 & - & 0.71 & 1.41 & 2.60 \\
\hline
\end{tabular}

Source: World Bank Data: https://databank.worldbank.org/

Considering the figures which show international tourism receipts obtained by Post-Soviet countries in 1996 when these countries gained new independence, it is seen that Russia was ahead of other countries with an income volume of 7102 million dollars. In addition, Table 2. Show that Estonia, Ukraine, Lithuania and Kazakhstan follow Russia with income figures of \$ 565 million, \$ 448 million, \$ 345 million, and \$ 258 million, respectively. Tourism revenues of other countries were below 100 million dollars. In the following years, the volume of tourism revenues increased in all countries. By 2018, it is seen that all countries whose data are known, except Azerbaijan and Tajikistan, have increased compared to 2017. The highest increase was seen in the international tourism receipts of Russia with a rate of $24.61 \%$, while Georgia follows a Russian growth rate with a rate of $18.41 \%$. When we evaluate 2018 tourism revenues in dollar terms, we can see that the leadership among these countries is again in Russia with 18670 million dollars. Georgia follows Russia with tourism revenues of \$ 3518 million. Apart from Kyrgyz Republic, Moldova and Tajikistan, all other countries whose data is known profit over \$ 1 billion in revenue.

Table 2. International tourism receipts of Post-Soviet countries

\begin{tabular}{lllllllllll}
\hline & \multicolumn{3}{l}{ International tourism receipts $(\mathrm{m} \ln \$)$} & \multicolumn{4}{c}{ Change in international tourism receipts (\%) } \\
& 1996 & 2015 & 2016 & 2017 & 2018 & 1996 & 2015 & 2016 & 2017 & 2018 \\
\hline Azerbaijan & 57 & 2,535 & 2,855 & 3,214 & 2,830 & -34.48 & -6.56 & 12.62 & 12.57 & -11.95 \\
Armenia & 18 & 956 & 988 & 1,140 & 1,237 & 28.57 & -3.82 & 3.35 & 15.38 & 8.51 \\
Belarus & 61 & 1,013 & 1,019 & 1,124 & 1,221 & 117.86 & -17.64 & 0.59 & 10.30 & 8.63 \\
Estonia & 565 & 1,893 & 1,916 & 2,126 & 2,332 & 25.00 & -16.90 & 1.22 & 10.96 & 9.69 \\
Georgia & - & 2,049 & 2,315 & 2,971 & 3,518 & - & 3.90 & 12.98 & 28.34 & 18.41 \\
Kazakhstan & 258 & 1,833 & 2,038 & 2,356 & 2,651 & 66.45 & -18.13 & 11.18 & 15.60 & 12.52 \\
Kyrgyz & & & & & & & & & & \\
Republic & 4 & 482 & 477 & 480 & 487 & -20.00 & 2.99 & -1.04 & 0.63 & 1.46 \\
Lithuania & 345 & 1,153 & 1,210 & 1,325 & 1,419 & 238.24 & -16.63 & 4.94 & 9.50 & 7.09 \\
Latvia & 231 & 895 & 899 & 951 & 1,057 & 524.32 & -6.09 & 0.45 & 5.78 & 11.15 \\
Moldova & 50 & 300 & 344 & 443 & 500 & -29.58 & -8.54 & 14.67 & 28.78 & 12.87 \\
Russian & & & & & & & & & & \\
Federation & 7,102 & 13,186 & 12,822 & 14,983 & 18,670 & 64.70 & -32.21 & -2.76 & 16.85 & 24.61 \\
Tajikistan & - & 146 & 150 & 172 & 171 & - & -33.70 & 2.47 & 14.71 & -0.41 \\
Turkmenistan & - & - & - & - & - & - & - & - & - & - \\
Ukraine & 448 & 1,662 & 1,723 & 2,019 & 2,269 & 134.55 & -26.59 & 3.67 & 17.18 & 12.38 \\
Uzbekistan & 15 & - & 579 & 835 & 1,314 & - & - & - & 44.21 & 57.37 \\
\hline
\end{tabular}

Source: World Bank Data: https://databank.worldbank.org/

Considering the arrivals statistics of the countries in the sample, we see that Russia attracted more tourists than other countries with the figure of 16.208 million in 1996. Ukraine, Estonia and Latvia follow Russia with 5.391 million, 
2.444 million and 1.713 million tourists, respectively. In the following years, an increase in the number of tourists accepted in all countries was observed, and even in 2018, it increased by $139.5 \%$ in Tajikistan and $98.7 \%$ in Uzbekistan compared to 2017. Since the statistics of Russia are not clear, it is not possible to say a clear idea about the number of tourists traveling to this country in 2018. From the data obtained, we see that the country with the highest number of tourist arrivals among Post-Soviet countries is Ukraine with 14104 million tourists. If we act on the sample, it is seen that Belarus, Kazakhstan, Latvia and Georgia follow Ukraine in the ranking of the countries that attract the most tourists.

Table 3. Total arrivals for main purpose

\begin{tabular}{lllllllllll}
\hline & \multicolumn{3}{l}{ Total arrivals for main purpose - Thousands } & \multicolumn{7}{c}{ Change in total arrivals (\%) } \\
\cline { 2 - 10 } & 1996 & 2015 & 2016 & 2017 & 2018 & 1996 & 2015 & 2016 & 2017 & 2018 \\
\hline Armenia & 13.0 & 1192.0 & 1259.6 & 1494.8 & 1651.8 & 8.3 & -1.0 & 5.7 & 18.7 & 10.5 \\
Azerbaijan & 210.0 & 2006.2 & 2248.8 & 2696.7 & 2849.6 & 125.8 & -12.7 & 12.1 & 19.9 & 5.7 \\
Belarus & - & 4386.0 & 10935.0 & 11060.0 & 11501.6 & - & -18.4 & 149.3 & 1.1 & 4.0 \\
Estonia & 2444.0 & - & - & - & - & 15.8 & - & - & - & - \\
Georgia & - & 5256.0 & 5392.7 & 6482.9 & 7203.3 & - & - & 2.6 & 20.2 & 11.1 \\
Kazakhstan & - & 6430.1 & 6509.4 & 7701.1 & 8789.3 & - & 1.5 & 1.2 & 18.3 & 14.1 \\
Kyrgyz & & & & & & & & & & \\
Republic & - & - & - & - & - & - & - & - & - & - \\
Latvia & 1713.0 & 6842.0 & 6797.0 & 7725.8 & 7775.2 & - & 9.5 & -0.7 & 13.7 & 0.6 \\
Lithuania & 832.0 & 2071.0 & 2296.0 & 2523.3 & 2824.8 & - & 0.4 & 10.9 & 9.9 & 11.9 \\
Moldova & - & - & - & - & - & - & - & - & - & - \\
Russian & & & & & & & & & - & - \\
Federation & 16208.0 & 33729.2 & - & - & - & 57.5 & 4.0 & - & - & - \\
Tajikistan & - & 414.0 & 345.0 & 432.0 & 1034.8 & - & 94.4 & -16.7 & 25.2 & 139.5 \\
Turkmenistan & 281.0 & - & - & - & - & 21.1 & - & - & - & - \\
Ukraine & 5391.0 & 12428.0 & 13333.2 & 14229.7 & 14104.1 & -1.7 & -2.2 & 7.3 & 6.7 & -0.9 \\
Uzbekistan & - & 1917.7 & 2027.0 & 2690.1 & 5346.2 & - & 3.0 & 5.7 & 32.7 & 98.7 \\
\hline
\end{tabular}

Source: United Nations World Tourism Organization (UNWTO): https://www.e-unwto.org/

If the travel purposes of the tourists are taken into consideration, it is seen that the tourists traveling to the Post-Soviet countries mostly travel for holidays, leisure and recreation. When we look at the table in general, tourists traveling to countries such as Azerbaijan, Armenia, Lithuania, Belarus on the basis of all years made more trips for business purposes compared to other countries. 2018 figures indicate that among the tourists accepted on a country basis, mostly travel for holidays, leisure and recreation purposes are made to Armenia with a rate of $48.40 \%$. It seems that the tourists traveling to Georgia, Azerbaijan, Latvia and Lithuania travel mostly for this purpose as well. It should be noted that we see that among those countries, tourists traveling to Ukraine and Kazakhstan travel for holidays, leisure and recreation purposes with a rate of 012.12 and 0.75 , respectively. Although the information is not included in the table, according to the UNWTO Statistics, the vast majority of the tourists traveling to these countries have traveled for other personal purposes (Ukraine - 99.5\%, Kazakhstan 85.3\%). 
Table 4. Share of arrivals for different purposes in Post-Soviet countries

\begin{tabular}{llllllllllll}
\hline & \multicolumn{2}{l}{$\begin{array}{l}\text { Share of arrivals } \\
\text { professionals }(\%)\end{array}$} & & for & business & and & \multicolumn{2}{l}{$\begin{array}{l}\text { Share of arrivals for holidays, leisure and } \\
\text { recreation }(\%)\end{array}$} \\
\hline & 1995 & 2015 & 2016 & 2017 & 2018 & 1995 & 2015 & 2016 & 2017 & 2018 \\
\hline Armenia & 16.67 & 35.40 & 31.90 & 23.90 & 27.30 & 66.67 & 48.74 & 49.80 & 52.80 & 48.80 \\
Azerbaijan & 37.63 & 31.52 & 30.76 & 30.94 & 27.63 & 50.54 & 34.87 & 32.77 & 32.67 & 38.18 \\
Belarus & - & 6.41 & 25.20 & 25.20 & 23.20 & - & 69.27 & 24.31 & 24.31 & 24.96 \\
Estonia & 17.30 & - & - & - & - & 61.61 & - & - & - & - \\
Georgia & - & 10.15 & 10.12 & 8.21 & 8.66 & - & 31.36 & 33.87 & 37.75 & 42.70 \\
Kazakhstan & - & 16.25 & 16.85 & 15.41 & 13.92 & - & 0.85 & 0.86 & 1.06 & 0.75 \\
Kyrgyz Republic & - & - & - & - & - & - & - & - & - & - \\
Latvia & - & 11.97 & 10.42 & 9.86 & 8.93 & - & 42.94 & 38.22 & 33.18 & 33.70 \\
Lithuania & - & 29.74 & 27.83 & 28.38 & 27.91 & - & 33.46 & 34.32 & 34.19 & 31.78 \\
Moldova & - & - & - & - & - & - & - & - & - & - \\
Russian Federation & 28.17 & 22.29 & - & - & - & 17.85 & 8.71 & - & - & - \\
Tajikistan & - & 5.31 & 8.41 & 8.10 & 0.52 & - & 6.28 & 8.99 & 23.84 & 7.13 \\
Turkmenistan & 12.93 & - & - & - & - & 22.84 & - & - & - & - \\
Ukraine & 14.64 & 0.33 & 0.27 & 0.66 & 0.38 & 34.20 & 1.11 & 1.34 & 0.28 & 0.12 \\
Uzbekistan & - & 7.27 & 8.54 & 6.89 & 2.28 & - & 8.70 & 8.67 & 7.67 & 8.57 \\
\hline
\end{tabular}

Source: United Nations World Tourism Organization (UNWTO): https://www.e-unwto.org/

\section{Data and Methodology}

In the study, two different indices were used to evaluate the competitiveness of Post-Soviet countries. Specifically, Balassa index was used to evaluate comparative advantage and EB index was used to evaluate competitive advantage. The revealed comparative advantage coefficient explained in the " $\mathrm{k}$ " sector in the " $\mathrm{t}$ " period of the country " $\mathrm{j}$ " is formulated by Balassa as follows.

$$
B_{k t}^{j}=\frac{\frac{X_{k t}^{j}}{X_{t}^{j}}}{\frac{X_{k t}^{w}}{X_{t}^{W}}}
$$

$X_{k t}^{j}$ : country j's exports of $\mathrm{k}$ goods in time period $\mathrm{t}, X_{t}^{j}$ : total exports of country $\mathrm{j}$ in time period $\mathrm{t}, X_{k t}^{w}$ : w total exports of $\mathrm{k}$ goods of the world countries in time period $\mathrm{t}, X_{t}^{w}$ : total exports of world countries in time period $\mathrm{t}$.

The numerator of the Balassa index is the share of the export of goods (sector) in national exports (\%); the denominator part represents the share of the export of the good (sector) in the world total exports. The values of the Balassa index determine whether the country has a comparative advantage or not. Namely;

If $B_{k t}^{j}>1$, country $\mathrm{j}$ export of $\mathrm{k}$ goods (sector) in period $\mathrm{t}$ is greater than its share in total world exports in the same period. The country has the revealed comparative advantage in the product (sector) and specializes;

If $B_{k t}^{j}<1$, country $\mathrm{j}$ export of $\mathrm{k}$ goods (sector) in period $\mathrm{t}$ is smaller than its share in total world exports in the same period. The country has the revealed comparative disadvantage in the product (sector) and is not specialized.

If $B_{k t}^{j}=1, \mathrm{j}$ country's exports of $\mathrm{k}$ goods (sector) in period $\mathrm{t}$ is equal to its share in total world exports in the same period. The level of specialization of the country in the particular product is the same as that of the world. 
Algieri et al. (2018) also define this index as the Revealed Competitive Advantage index because they include the import side of the trade in the EB index they developed. The formula of the index aiming to calculate the international competitiveness of the $\mathrm{j}$ country at $\mathrm{t}$ time in the $\mathrm{k}$ sector is as follows:

$$
E B_{k t}^{j}=\frac{\frac{X_{k t}^{j}}{X_{t}^{j}}}{\frac{X_{k t}^{W}}{X_{t}^{W}}} / \frac{\frac{M_{k t}^{j}}{M_{t}^{j}}}{\frac{M_{k t}^{W}}{M_{t}^{W}}}
$$

$X_{k t}^{j}$ : country j's exports of $\mathrm{k}$ goods in time period $\mathrm{t}, X_{t}^{j}$ : total exports of country $\mathrm{j}$ in time period $\mathrm{t}, X_{k t}^{w}: \mathrm{w}$ total exports of $\mathrm{k}$ goods of the world countries in time period $\mathrm{t}, X_{t}^{w}$ : total exports of world countries in time period $\mathrm{t}, M_{k t}^{j}$ : country j's imports of k goods in time period t, $M_{t}^{j}$ : total imports of k goods of the j country in time period t, $M_{k t}^{w}$ : total k goods imports of world countries in time period $\mathrm{t}, M_{t}^{w}$ : total imports of world countries in time period t.

The Balassa index, which has been formulated above, constitutes the numerator of the EB index, and the denominator part is the ratio of the share of a sector's imports in the country's total imports to the share of this sector's total imports in the total imports worldwide. Here, X represents the export and M represents the import data.

While evaluating the competition levels of the countries, the classification proposed by Hinloopen \& Van Marrewijk (2001) was used:

Class a: $0<E B_{k t}^{j} \leq 1$ competitive disadvantage;

Class b: $1<E B_{k t}^{j} \leq 2$ weak competitive advantage;

Class c: $2<E B_{k t}^{j} \leq 4$ medium competitive advantage;

Class d: ...EB $B_{k t}^{j}>4$ strong competitive advantage.

In the study, the World Development Indicators database, which is accessed from the World Bank website, was used. Specifically, the international tourism receipts (\% of total exports) and international tourism expenditures (\% of total imports) series are subject to calculations. Since the database does not contain data related to Turkmenistan, the mentioned country is excluded from the sample.

\section{Results and Discussion}

As stated above, calculations were made on two different indices in order to evaluate the international comparative superiority and competitiveness within the scope of the tourism economy of Post-Soviet countries. Table 5. provides us with statistics on Balassa indices. In the years after 2008, we see an increase in the number of sample countries that have a comparative advantage in the international context. That is to say, in 2008, Armenia was settled with a 5.12 coefficient, as the country with the most comparative advantage. Together with Kyrgyz Republic, Georgia, Moldova, Estonia and Ukraine, we see that 6 countries in total have a comparative advantage over other world countries. In 2018, the country with the most comparative advantage is Georgia with 5,997 Balassa index. We see that Tajikistan, Azerbaijan and Uzbekistan were included in the list with the comparative advantage in 2008 with the value of $1.684,1.550$ and 1.410, respectively. Also, the data shows us that Ukraine no longer has an international comparative advantage. It is observed that Russia's Balassa index, which has more tourist revenues than other Post-Soviet countries, is less than 1 . The reason for this can be explained by the fact that the tourism revenues stated in Table 1 coincide with a small ratio of $1.13 \%$ of the Russian GDP. In summary, based on these data, it is possible to say that Georgia had more comparative advantage in 2018 compared to other sample countries, Armenia, Kyrgyz Republic, Moldova, Tajikistan, Azerbaijan, Estonia and Uzbekistan followed Georgia in decreasing order. 
Table 5. Balassa index of Post-Soviet countries in the tourism sector

\begin{tabular}{llllllllllll}
\hline & 2008 & 2009 & 2010 & 2011 & 2012 & 2013 & 2014 & 2015 & 2016 & 2017 & 2018 \\
\hline Azerbaijan & 0.212 & 0.375 & 0.478 & 0.731 & 1.273 & 1.241 & 1.373 & 1.934 & 2.385 & 2.421 & 1.684 \\
Armenia & 5.127 & 5.720 & 5.354 & 5.018 & 5.182 & 4.883 & 4.936 & 4.657 & 4.145 & 3.951 & 3.991 \\
Belarus & 0.285 & 0.362 & 0.387 & 0.290 & 0.336 & 0.446 & 0.467 & 0.471 & 0.499 & 0.459 & 0.438 \\
Estonia & 1.765 & 1.420 & 1.242 & 1.129 & 1.151 & 1.621 & 1.722 & 1.632 & 1.513 & 1.551 & 1.550 \\
Georgia & 2.439 & 2.640 & 3.116 & 3.683 & 4.607 & 4.548 & 4.616 & 5.125 & 5.503 & 5.873 & 5.997 \\
Kazakhstan & 0.291 & 0.386 & 0.322 & 0.307 & 0.415 & 0.442 & 0.429 & 0.549 & 0.720 & 0.654 & 0.599 \\
Kyrgyz Republic & 3.750 & 2.013 & 1.642 & 2.283 & 2.460 & 2.610 & 2.350 & 3.037 & 2.902 & 2.788 & 2.840 \\
Latvia & 0.979 & 0.993 & 0.848 & 0.850 & 0.766 & 0.808 & 0.818 & 0.831 & 0.788 & 0.754 & 0.760 \\
Lithuania & 0.800 & 0.778 & 0.689 & 0.751 & 0.696 & 0.639 & 0.649 & 0.618 & 0.558 & 0.512 & 0.489 \\
Moldova & 2.408 & 2.198 & 1.939 & 1.667 & 1.826 & 1.814 & 1.827 & 1.842 & 1.925 & 2.122 & 2.197 \\
Russian Federation & 0.534 & 0.564 & 0.511 & 0.534 & 0.537 & 0.581 & 0.570 & 0.513 & 0.567 & 0.545 & 0.558 \\
Tajikistan & 0.726 & 0.509 & 2.866 & 3.163 & 3.872 & 4.238 & 4.339 & 2.705 & 2.442 & 2.279 & 2.322 \\
Ukraine & 1.440 & 1.307 & 1.220 & 1.167 & 1.227 & 1.236 & 0.570 & 0.531 & 0.550 & 0.560 & 0.582 \\
Uzbekistan & - & - & - & - & - & - & - & - & 0.806 & 1.005 & 1.410 \\
\hline
\end{tabular}

Table 6, reflects the Revealed Competitive Advantage indices developed by Algieri et al. (2018). As these indices take into account the export data and import data, which differ from the Balassa index, the list of Post-Soviet countries, which have competitive advantages compared to the world countries, differs slightly from the list of Post-Soviet countries which have comparative advantage. Among the countries included in the sample in 2008, Georgia, Armenia, Kyrgyz Republic, Moldova, Estonia and Ukraine countries are in the list of countries with international competitive advantage, which led by Tajikistan with 13,635 coefficient. By 2018, Tajikistan, the leader of the ranking again, with index value of 19.892, and is followed by Georgia, Kyrgyz Republic, Moldova, Latvia, Estonia, Armenia, Lithuania, and Belarus, with an equivalent of 4.331, 2.214, 2.062, 1.330, 1.314, 1.172, 1.117, 1.006, respectively. Unlike the comparative advantage index, these indices indicate that instead of Azerbaijan and Uzbekistan, Belarus and Lithuania have competitive advantage. When we evaluate the data based on the classification proposed by Hinloopen \& Van Marrewijk (2001), it is concluded that Tajikistan and Georgia have strong competitive advantage worldwide, Kyrgyz Republic and Moldova have medium competitive advantage, Latvia, Estonia, Armenia, Lithuania and Belarus have weak competitive advantages.

Table 6. Extended Balassa index of Post-Soviet countries in the tourism sector

\begin{tabular}{llllllllllll}
\hline & 2008 & 2009 & 2010 & 2011 & 2012 & 2013 & 2014 & 2015 & 2016 & 2017 & 2018 \\
\hline Azerbaijan & 0.272 & 0.443 & 0.309 & 0.325 & 0.442 & 0.433 & 0.513 & 0.839 & 1.019 & 0.971 & 0.783 \\
Armenia & 2.744 & 2.668 & 2.046 & 1.644 & 1.589 & 1.442 & 1.473 & 1.256 & 1.121 & 1.122 & 1.172 \\
Belarus & 0.707 & 0.849 & 1.028 & 0.956 & 0.910 & 0.843 & 0.937 & 0.998 & 1.126 & 1.018 & 1.006 \\
Estonia & 1.716 & 1.525 & 1.419 & 1.324 & 1.468 & 1.464 & 1.599 & 1.516 & 1.376 & 1.409 & 1.314 \\
Georgia & 2.819 & 2.625 & 3.127 & 3.859 & 4.669 & 4.258 & 4.919 & 4.702 & 4.431 & 4.229 & 4.331 \\
Kazakhstan & 0.552 & 0.673 & 0.516 & 0.434 & 0.367 & 0.402 & 0.383 & 0.513 & 0.675 & 0.649 & 0.625 \\
Kyrgyz & & & & & & & & & & & \\
Republic & 2.027 & 1.547 & 1.205 & 1.426 & 1.559 & 1.863 & 1.598 & 1.776 & 1.588 & 2.204 & 2.214 \\
Latvia & 0.834 & 0.851 & 0.931 & 0.997 & 1.090 & 1.187 & 1.359 & 1.450 & 1.245 & 1.280 & 1.330 \\
Lithuania & 0.905 & 0.827 & 1.072 & 1.450 & 1.308 & 1.166 & 1.257 & 1.213 & 1.157 & 1.127 & 1.117 \\
Moldova & 1.878 & 1.564 & 1.479 & 1.339 & 1.365 & 1.387 & 1.453 & 1.439 & 1.729 & 1.970 & 2.062 \\
Russian & & & & & & & & & & & \\
Federation & 0.386 & 0.346 & 0.294 & 0.295 & 0.259 & 0.249 & 0.264 & 0.243 & 0.365 & 0.330 & 0.318 \\
Tajikistan & 13.635 & 14.660 & 14.618 & 20.535 & 27.629 & 28.962 & - & - & 19.472 & 27.428 & 19.892 \\
Ukraine & 1.586 & 1.109 & 1.110 & 1.142 & 1.167 & 1.037 & 0.437 & 0.318 & 0.307 & 0.305 & 0.319 \\
Uzbekistan & - & - & - & - & - & - & - & - & 0.427 & 0.517 & 0.782 \\
\hline
\end{tabular}


Regarding the results achieved, it is possible to say that the fact that the highest Balassa index of Georgia in 2018, which means this country has more comparative advantage among other Post-Soviet countries can be regarded as meaningful as Georgia's tourism income constitutes $20 \%$ of its GDP. However, the EB index reveals controversial findings. Namely, the point that draws attention here is the high EB value of Tajikistan in 2008-2018. The information in Table 1 shows that the share of Tajikistan's tourism revenues in the GDP in 2018 was 2.27\%. On a sector basis with such a low impact on the GDP of the country, it may not be meaningful that this country has a remarkably large competition index. The fact that Tajikistan's Balassa index is 2,322 gives an idea about the fact that the ED index is such a large precedent, since the international tourism expenditures of the mentioned country`s citizenships are low. World Bank statistics also support this idea with Tajikistan's international tourism expenditures being $0.12 \%$ of total imports.

In future studies, it is recommended to carry out studies to determine the sources of comparative or competitive advantages of countries. Particularly, it is useful to examine the socio-cultural, economic and environmental factors that affect a country that how they reach the position of comparative or competitive country over the years. In addition, a new index can be considered that focuses on the number of arrivals to assess the competitiveness of countries in the tourism sector.

\section{Conclusion}

For Post-Soviet countries, also known as developing countries, the tourism industry is an attractive industry due to its feature of creating high foreign currency revenues at low costs. Considering the country data in general, it is observed that countries have made great progress in the tourism sector today compared to the first years of their independence. Namely, in 1996, only one country - Russia achieved international tourism receipts over \$1 billion (clearly, $\$ 7,102$ billion), but by 2018, the number of these countries increased to 10, now Azerbaijan, Armenia, Belarus, Estonia, Georgia, The states of Kazakhstan, Lithuania, Latvia, Ukraine and Uzbekistan have also achieved international tourism receipts of over $\$ 1$ billion.

Moreover, a considerable increase in the number of arrivals was observed between 1996 and 2018. Namely, in 1996, total arrivals in only 4 countries were over 1 million, and in 2018, over one million total arrivals took place in all 10 countries whose data were announced. To be more precise, 6 of these countries - Ukraine (14.104 million), Belarus (11.501 million), Kazakhstan (8.789 million), Latvia (7.775 million), Georgia (7.203 million) and Uzbekistan (5.346 million) - over 5 million tourists were able to attract in 2018.

The results of this research, which we set out to determine to what extent the mentioned countries benefit from these advantages of the tourism sector, show that Georgia is in an advantageous position at an international level compared to other Post-Soviet countries. Both Balassa indices and Extended Balassa indices reveal outputs that this country has a strong competitive advantage. The fact that the tourism revenues of this country constitute one fifth of the country's GDP also indicates how important this sector is for Georgia.

To conclude, we see that the majority of Post-Soviet countries have internationally comparative and competitive advantage. The main reason for this was that these countries remained closed to the outside world for a long time, and therefore they were always the focus of attention for foreign citizens. However, both natural beauties and historical features of these countries are one of the main factors that arouse curiosity in foreigners. Considering this tourism potential of Post-Soviet countries and the findings obtained as a result of the research, it is recommended that these countries develop tourism industries by investing more in tourism economies and making more promotional activities.

\section{References}

Akbulaev, N. (2004). Kırgızistan ekonomisinde turizm sektörünün yeri ve önemi. ISGUC The Journal of Industrial Relations and Human Resources, 6(1).

Akbulaev, N., \& Mirzayeva, G. (2020). Analysis of a paired regression model of the impact of income from international tourism on the foreign trade balance. African Journal of Hospitality, Tourism and Leisure, 9(1), 1-16.

Algieri, B. (2006). International tourism specialisation of small countries. International Journal of Tourism Research, $8(1), 1-12$

Algieri, B., Aquino, A., \& Succurro, M. (2018). International competitive advantages in tourism: An eclectic view. Tourism Management Perspectives, 25, 41-52.

Balassa, B. (1965). Trade Liberalisation and Revealed Comparative Advantage 1. The Manchester School, 33(2), 99-123. 
Calderwood, L., \& Soshkin, M. (2019). The Travel \& Tourism Competitiveness Report 2019. World Economic Forum. Retrieved from http://www3. weforum. org/docs/WEF_TTCR_2019. pdf

Çivi, E. (2001). Rekabet gücü: literatür araştırması. Yönetim ve Ekonomi: Celal Bayar Üniversitesi İktisadi ve İdari Bilimler Fakültesi Dergisi, 8(2), 21-38.

Das, J., \& Dirienzo, C. (2010). Tourism Competitiveness and Corruption: A Cross-Country Analysis. Tourism Economics, 16(3), 477-492. https://doi.org/10.5367/000000010792278392

Erkan, B., \& Bozduman, E. T. (2019). Analysis of Specialization and Competition Level in Turkey's Tourism Sector. Kocaeli Üniversitesi Sosyal Bilimler Dergisi, 2(38), 1-12.

Gümüş, A., \& Hiziroğlu, M. (2015). Measuring And Explaining Turkey's Competitiveness in Services Using Balassa Index and Diamond Model. Journal of Business Research Turk, 7(2), 195-213.

Hinloopen, J., \& Van Marrewijk, C. (2001). On the empirical distribution of the Balassa index. Weltwirtschaftliches Archiv, 137, 1-35. https://doi.org/10.1007/BF02707598

Jackman, M., Lorde, T., Lowe, S., \& Alleyne, A. (2011). Evaluating tourism competitiveness of small island developing states: a revealed comparative advantage approach. Anatolia, 22(3), 350-360.

Kantarci, K., \& Develioglu, K. (2013). The impact of travel \& tourism competitiveness factors on tourism performance: The case of Silk Road countries. International Conference on Economic and Social Studies (ICESOS'13), 10, p. 11.

Kayar, Ç. H., \& Kozak, N. (2010). Measuring Destination Competitiveness: An Application of the Travel and Tourism Competitiveness Index (2007). Journal of Hospitality Marketing \& Management., 19(3), 203-216. https://doi.org/10.1080/19368621003591319

Kuşat, N. (2019). Türkiye Turizm Sektörünün Dünya Sektör Liderleri Karşisindaki Rekabet Gücü0. Dokuz Eylül Üniversitesi İsletme Fakültesi Dergisi, 20(1), 141-165.

Leung, X. Y., \& Baloglu, S. (2013). Tourism competitiveness of Asia Pacific destinations. Tourism Analysis,, 18(4), 371-384.

Liesner, H. H. (1958). The European common market and British industry. The Economic Journal, 68(270), 302-316.

Miral, Z. C. (2006). Açıklanmış karşılaştırmalı üstünlükler ve Türkiye'nin Avrupa Birliği'ne karşı rekabet gücü: Seçilmiş tarımsal ürünler için bir uygulama. Doctoral dissertation, DEÜ Sosyal Bilimleri Enstitüsü.

Nazmfar, H., Eshghei, A., Alavi, S., \& Pourmoradian, S. (2019). Analysis of travel and tourism competitiveness index in middle-east countries. Asia Pacific Journal of Tourism Research, 24(6), 501-513.

Ricardo, D. (1821). On the principles of political economy. London: J. Murray.

Seyoum, B. (2007). Revealed comparative advantage and competitiveness in services. . Journal of Economic Studies.

United Nations World Tourism Organization (UNWTO). (2020). World tourism barometer. Retrieved from https://www.e-unwto.org/doi/pdf/10.18111/wtobarometereng.2020.18.1.1

United Nations World Tourism Organization (UNWTO). (2019). International tourism highlights. Retrieved from https://www.e-unwto.org/doi/pdf/10.18111/9789284421152

Utkulu, U., \& Seymen, D. (2004). Revealed Comparative Advantage and Competitiveness: Evidence for Turkey vis-a-vis the EU/15. The European Trade Study Group 6th Annual Conference ETSG. Nottingham.

Vollrath, T. L. (1991). A Theoretical Evaluation of Alternative Trade Intensity Measures of Revealed Comparative Advantage. Weltwirtschaftliches Archiv, 130, 265-279.

World Bank Data. (n.d.). Retrieved from https://www.worldbank.org/

World Tourism Organization. (n.d.). Retrieved from https://www.e-unwto.org/

\section{Copyrights}

Copyright for this article is retained by the author(s), with first publication rights granted to the journal.

This is an open-access article distributed under the terms and conditions of the Creative Commons Attribution license (http://creativecommons.org/licenses/by/4.0/). 